\title{
PERILAKU KONSUMEN DALAM KEPUTUSAN PEMBELIAN ITEM PADA GAME ONLINE PUBG MOBILE
}

\author{
${ }^{1} \mathrm{M}$ Prayogi Eko Saputro1, ${ }^{2}$ Nova Adhitya Anandha2, ${ }^{3}$ Reza muhammad Rizqi3 \\ ${ }^{1 *}$ Fakultas Ekonomi dan Bisnis Universitas Teknologi Sumbawa \\ ${ }^{2}$ Dosen Fakultas Ekonomi dan Bisnis Teknologi Sumbawa \\ ${ }^{3}$ Dosen Fakultas Ekonomi dan Bisnis Teknologi Sumbawa \\ 1*Email: Younggirlcom3@Gmail.com \\ 2Email: Nova.adhitya.ananda@uts.ac.id \\ 3Email: Reza.muhammad.rizai@uts.ac.id
}

\begin{abstract}
Abstrak
Saputro, Muhammad Prayogi Eko (2019). "Perilaku Konsumen Dalam Keputusan Pembelian Item Pada Game Online PUBG Mobile". Skripsi. Program studi manajemen, fakultas ekonomi dan bisnis, universitas teknologi sumbawa. Pembimbing: (I) Nova Adhitya Ananda, M.M, (II) Reza Muhammad Rizqi, M.Ak. Penelitian ini merupakan hasil penelitian kualitatif desktriptif yang bertujuan menjawab tentang bagaimana perilaku konsumen dalam keputusan pembelian item pada game online PUBG mobile. Metode pendekatan dengan porposive sampling dalam menentukan informan pada penelitian ini. Pengumpulan data dilakukan dengan wawancara kepada informan dan observasi, pengamatan lokasi pada penelitian ini yaitu pada cafe ruang temu. Permasalahan pada penelitian ini, kenapa orang mau membeli item pada game online PUBG mobile yang tidak ada kegunaannya di dunia nyata. Penelitian ini didasari oleh karakteristik perilaku konsumen yaitu faktor pribadi diantaranya: faktor usia dan tahap siklus hidup, faktor pekerjaan dan keadaan ekonomi, faktor gaya hidup, dan faktor kepribadian dan konsep diri.
\end{abstract}

Kata kunci : Perilaku konsumen, keputusan pembelian item game online

\section{Abstract}

Saputro, Muhammad Prayogi Eko (2019). "Consumer Behavior in Decisions Purchasing Items at PUBG Mobile Online Games", Thesis. Study program Management Faculty of Economics and business University of Technologi Sumbawa. Supervisor (I) Nova Adhitya Ananda, M.M, (II) Reza Muhammad Rizqi, M.Ak. This resereach is the result of descriptive qualitatif resereach aimed at answer about how consumer behavior in purcashing desicions in the online game PUBG Mobile the method of approach with purposive sampling in determining informants in this study. Data collection is done with interviews with informantsand observations, location observations in this study namely in the intersection cafe. 


\section{JURNAL MANAJEMEN DAN BISNIS VOL. 01 NO.02 2019}

Jurnal.uts.ac.id

The problem in this study, why do people buy items on PUBG Mobile Online Games that are of on use in the world this resereach is based on the characteristics of consumer behavior namely personal factors including factors and economics, lifestyle factors, and personality factors and self-concepts.

\section{Keywords : Consumer behavior, desicions to purchase online game items}

\section{PENDAHULUAN}

Perkembangan teknologi yang kian pesat melahirkan perangkat perangkat baru yang mampu menjawab kebutuhan individu. Perkembangan teknologi yang khususnya berhubungan dengan smartphone yang memiiliki operasi sistem android, kemunculan smartphone berbasis android memang mampu memberi berbagai manfaat serta kemudahan bagi penggunanya. Smartphone berbasis android merupakan telepon seluler yang memiliki kemampuan yang melebihi telepon seluler biasa, mulai dari fitur, resolusi layar, hingga sistem operasi didalamnya. Hingga saat ini smartphone berbasis android yang paling banyak digunakan, dari seluruh pengguna smartphone didunia, $87 \%$ memilih menggunakan smartphone berbasis android sebagai operasi sistem dalam smartphone mereka, Gadgetren.com (2016).

Seiring dengan perkembangan teknologi yang mampu membawa perubahan bagi kehidupan manusia, salah satu hasil dari perkembangan teknologi adalah internet. Seperti yang kita ketahui koneksi internet saat ini telah melekat erat dengan kehidupan orang sebagian, karena dengan adanya koneksi internet, hal tersebut dapat mempermudah pekerjaan seseorang, internet saat ini telah sangat mudah diakses oleh semua orang, ditambah lagi dengan kemunculan smartphone yang dapat mengakses internet yang memberi kemudahaan mengakses bagi semua orang, yang dapat digunakan kapan saja dan dimana saja. Sementara itu penduduk di Indonesia mencapai 262 juta orang, dan 143.26 juta masyarakat indonesia merupakan pengguna internet aktif. Durasi pengguna internet di Indonesia per hari paling besar terletak dalam kurun waktu 1-3 jam 43,89\%, lalu 4-7 jam 29,63\% dan lebih dari 7 jam 26,48. Adapun jenis layanan yang diakses oleh pengguna internet mulai dari membuka aplikasi chatting $89,35 \%$, lalu $87,13 \%$ membuka media sosial dan $57,13 \%$ untuk membuka game online, Kompas.com (2018). Aplikasi chatting seperti whatsaap dan aplikasi

sejenisnya menjadi prioritas para pengguna internet di Indonesia, kemudian yang kedua ada media sosial seperti facebook, instagram dan lain-lain yang membuat para pengguna internet tidak ketinggalan akan informasi, dan yang terakhir ada game online, dengan populasi masyarakat Indonesia yang aktif akan internet mencapai 143.26 membuat $57,13 \%$ menjadi angka yang cukup besar. Menurut Adam \& Rollings (2007), game online merupakan permainan yang dapat diakses oleh banyak pemain, dimana mesin-mesin yang digunakan pemain dihubungkan oleh suatu jaringan. Game online itu sendiri memiliki jenis aliran yang bermacam-macam, salah satunya adalah game yang berjenis battle royale. Player Unknown Battle Ground atau yang dikenal dengan 
singkatan PUBG mobile adalah salah satu game online dengan aliran game berjenis battle royale. Dimana para pemainnya dapat bermain dengan seratus orang sekaligus, dalam permainan ini pemain dapat bermain solo (satu orang), tim duo (dua orang) dan tim squad (tiga sampai empat orang), serta dapat mengundang teman untuk bergabung ke dalam permainan sebagai tim, Wikipedia (2018).

Alur game online PUBG mobile umumnya sama dengan game yang berjenis battle royale lainnya, dimana saat para pemain mulai menjalankan game mereka akan ditempatkan pada suatu pesawat yang telah disediakan. para pemain akan memilih lokasi tertentu dan terjun dengan menggunakan parasut, lalu para pemain akan mencari persediaan amunisi, senjata, dan perlengkapan bertahan hidup lainnya. Kemudian pada waktu tertentu batasan area yang ditandai dengan bundaran putih akan muncul dan bundaran putih tersebut akan mengecil seiring waktu yang telah ditentukan. Hal tersebut memaksa sekaligus memudahkan para pemain untuk saling bertemu dan saling mengeleminasi sehingga dapat ditentukan satu orang atau satu tim yang berhak menjadi pemenang.

game PUBG mobile memiliki kepopuleran yang cukup tinggi baik di indonesia maupun di seluruh dunia, kepopuleran game PUBG mobile saat ini sangatlah berkembang pesat, menurut selular.com (2018) pendapatan PUBG mobile mencapai 32,5 juta dollar, dan terus meningkat setiap harinya. Melihat hal tersebut perusahaan tentunya mendapatkan keuntungan tersendiri dari pengunduhan game maupun dengan penjualan yang tersedia didalam game. Selain dikenal karena kepopulerannya, game PUBG mobile memang menampilkan visual yang memungkinkan bagi pemainnya sungguh menikmati keseruan yang ditawarkan oleh game tersebut. Banyak sekali orang yang rela menghabiskan waktunya seharian demi mengejar rank yang merupakan hasil bermain mereka. Ditengah maraknya isu politik yang terjadi seperti sekarang ini, hal tersebut justru diabaikan oleh sebagian orang yang telah ketagihan akan game online PUBG mobile tersebut.

Setiap game online pastinya mempunyai mata uang virtual tersendiri, begitu pula dengan PUBG mobile, mata uang virtual PUBG mobile biasa disebut dengan Unknown Cash atau lebih dikenal dengan sebutan UC, dan UC tersebut di dapatkan melalui pembelian dengan menggunakan mata uang asli. Seseorang yang membeli UC pada game PUBG mobile memiliki tujuan agar dapat melakukan pembelian yang telah tersedia dalam game. Berikut adalah tabel penjualan unknown cash game PUBG mobile pada salah satu situs penjualan resmi.

Tabel 1.1. Penjualan UC, 2019

\begin{tabular}{|l|l|}
\hline \multicolumn{1}{|c|}{ Nama Toko Online } & $\begin{array}{c}\text { Jumlah Produk } \\
\text { (Paket UC) } \\
\text { Terjual }\end{array}$ \\
\hline Center Cegel Seal & 1699 \\
\hline Jago Data Purwokerto & 1965 \\
\hline Donikhun & 735 \\
\hline Sawarginet & 263 \\
\hline Wes Store & 243 \\
\hline
\end{tabular}

Sumber: Shopee.co.id

Jika konsumen PUBG mobile telah membeli UC, maka hal tersebut dapat memberikan hak bagi konsumen untuk membelanjakan apa saja yang mereka ingin belanjakan dalam game PUBG mobile. Salah satu pembelian yang disediakan oleh game PUBG mobile adalah royale pass elite, 


\section{JURNAL MANAJEMEN DAN BISNIS VOL. 01 NO.02 2019}

\section{Jurnal.uts.ac.id}

pembelian royale pass elite memiliki tujuan untuk menyelesaikan misi yang ada didalam game, Ketika misi tersebut terselesaikan maka pemain akan mendapatkan imbalan berupa hadiah menarik dan unik yang hanya bisa didapatkan dengan menyelesaikan misi royale pass elite, selain membeli royale pass elite yang betujuan untuk menyelesaikan misi dan mendapatkan imbalan hadiah, royale pass elite juga memberikan keistimewahan bagi seseorang yang melakukan pembelian, keistimewahan tersebut dimana sebelum pemain diterjunkan ke area pertempuran dan seseorang yang telah membeli royale pass elite dan mencapai pembelian tertinggi maka nama karakter pemain akan tercantum dilayar game dan dapat dilihat oleh semua pemain yang berada pada satu server yang sama.

Tercantumnya nama karakter pemain pada layar game akan memberi kesan tersendiri bagi seseorang yang telah melakukan pembelian royale pass elite hingga level tertinggi, keistimewan tersebut sebenarnya tidak sebanding dengan uang yang telah mereka keluarkan, pembelian misi royale pass elite yang mencapai level maksimal membutuhkan sekitar 9.200 UC atau setara dengan RP 1.675.000, Youtube.com (2019), secara tidak langsung hal tersebut menyatakan bahwa pembelian misi Royale pass adalah sebuah pembelian yang cukup mahal dalam kategori game. Selain penjualan royale pass elite terdapat juga penjualan Item/skin unik yang terdapat pada shop PUBG mobile, item-item tersebut memiliki jenis yang beragam, mulai dari skin karakter, skin kendaraan dalam game, dan skin-skin senjata yang unik. Item-item tersebut memang terlihat sangat mewah dan dapat membuat tampilan dari karakter seseorang menjadi lebih menarik. akan tetapi, item-item tersebut sama sekali tidak berpengaruh terhadap kekuatan fisik dan tidak mempengaruhi damage senjata dari karakter pemain, artinya jika seseorang yang menggunakan Item dengan seseorang yang tidak menggunakan item akan memiliki kekuatan fisik dan damage senjata yang sama.

Item-item yang ditawarkan oleh game online PUBG mobile juga memiliki harga yang relatif tinggi, walaupun dengan harganya yang tinggi, tidak sedikit pula konsumen yang melakukan pembelian. Padahal PUBG mobile hanyalah sebuah game yang hanya berlaku di dunia maya dan Item-item tersebut tidak berlaku di dunia nyata. Konsumen yang melakukan pembelian dalam game memiliki tujuan yang berbeda-beda atau mungkin saja terdapat faktorfaktor lain yang mendorong konsumen agar melakukan suatu pembelian dalam game online PUBG mobile. Di zaman serba modern seperti saat ini, pembelian terhadap item dalam game PUBG mobile bukanlah hal asing bagi konsumennya, karena kemudahan yang telah disediakan oleh pihak perusahaan, Tetapi penting juga bagi perusahaan untuk mengetahui faktor apa saja yang mempengaruhi perilaku konsumen dalam keputusan pembelian agar dapat mempertahankan eksistensi perusahaan tersebut.

Menurut Kotler \& Amstrong (2014), keputusan pembelian merupakan bagian dari perilaku konsumen, perilaku konsumen yaitu studi tentang bagaimana individu, kelompok, dan organisasi memilih, membeli, menggunakan, dan bagaimana barang, jasa, ide atau pengalaman untuk memuaskan kebutuhan dan keinginan mereka. Keputusan pembelian tidak dapat dipisahkan dari sifat seorang konsumen, oleh karena itu konsumen cenderung memiliki kebiasaan yang berbeda-beda dalam hal melakukan suatu pembelian. Sebelum melakukan pembelian terhadap suatu produk konsumen akan melalui beberapa tahapan, pada 
tahap awal konsumen terlebih dahulu akan melakukan pengenalan masalah terkait dengan apa yang menjadi kebutuhannya yang belum terpenuhi, kemudian pencarian informasi yang berkaitan dengan produk yang akan dibeli, tahap ketiga melakukan pembelian terhadap produk dan mengkonsumsi produk yang telah dibeli, kemudian tahap terakhir akan melakukan penilaian terhadap suatu produk dan mempertimbangkan kembali apakah ia akan melakukan pembelian ulang atau tidak. Menurut Kotler dan Keller (2008), terdapat faktor-faktor yang mempengaruhi perilaku konsumen dalam melakukan keputusan pembelian terhadap suatu produk yaitu: faktor budaya, faktor sosial, faktor pribadi dan faktor psikologis.

Menurut Kotler dan Keller (2016) keputusan pembelian konsumen juga dipengaruhi oleh karakteristik pribadi, karakteristik tersebut meliputi, usia dan tahap siklus hidup, pekerjaan dan keadaan ekonomi, gaya hidup, serta kepribadian dan konsep diri pembeli. Pada faktor usia dan tahap siklus hidup, seorang yang membeli suatu barang atau jasa akan berbeda sepanjang hidupnya, oleh karena itu selera dan kebutuhan seseorang pun juga ikut mengalami perbedaan dari masa ke masa, pada faktor usia dan siklus hidup dapat diartikan sebagai konsumen yang ingin membeli suatu produk memiliki tingkatan usia dan selera terhadap suatu produk yang akan dibeli. Kemudian pada faktor pekerjaan dan keadaan ekonomi dapat mempengaruhi keputusan pembelian seseorang, jika seseorang menginginkan suatu barang tetapi melihat kondisi keuangannya dan pendapatannya tidak sesuai dengan harga barang yang ia inginkan, maka barang tersebut mungkin saja tidak akan terbeli, atau mungkin saja terbeli, lantaran ada alternatif lain yang harus dilalui terlebih dahulu.
Faktor gaya hidup, gaya hidup seseorang yang berasal dari sub-budaya, kelas sosial, dan pekerjaan. Gaya hidup menggambarkan keseluruhan diri seseorang yang berinteraksi dengan lingkungannya, secara luas didefinisikan sebagai cara hidup seseorang yang menghabiskan waktu mereka (aktivitas), apa yang mereka anggap penting dalam lingkungannya (ketertarikan) dan apa yang mereka pikirkan tentang diri mereka sendiri dan dunia sekitarnya (opini), jika seseorang memiliki gaya hidup didunia internet kemudian suka memainkan game online dan game online tersebut menawarkan penjualan item-item yang menarik, maka hal tersebut akan memungkinkan seseorang untuk melakukan suatu pembelian yang terdapat pada game. Kemudian faktor terakhir adalah kepribadian dan konsep diri, kepribadian merupakan karakteristik psikologis seseorang, karakteristik seseorang tentunya selalu berbeda dengan orang lainnya, jika seorang individu memiliki kepribadian yang suka akan hal-hal berbau aksi atau menantang, maka hal tersebut akan mencerminkan pola konsumsi terhadap produk dari individu tersebut.

Dari latar belakang masalah yang telah diuraikan diatas maka rumusan masalah dalam penelitian ini yaitu, bagaimana perilaku konsumen dalam keputusan pembelian item pada game PUBG mobile?

\section{TINJAUAN PUSTAKA}

\subsection{Perilaku Konsumen}

Menurut Kotler dan Keller (2008) perilaku konsumen adalah studi tentang bagaimana individu, kelompok, dan organisasi memilih, membeli, menggunakan, dan bagaimana barang, jasa, ide, atau pengalaman untuk memuaskan kebutuhan dan keinginan mereka. Keragaman yang dimiliki konsumen merupakan hal menarik 


\section{JURNAL MANAJEMEN DAN BISNIS VOL. 01 NO.02 2019}

Jurnal.uts.ac.id

untuk dipelajari, karena konsumen dapat mencerminkan seorang individu mulai dari usia, latar belakang budaya, pendidikan dan keadaan ekonomi. Tujuan pemasaran pada suatu perusahaan adalah untuk memperoleh keuntungan yang didapatkan melalui konsumen, jika konsumen merasa puas dan kebutuhannya terpenuhi, hal tersebut akan berdampak pada penjualan produk yang telah diproduksi oleh perusahaan. Jika penjualan produk pada suatu perusahaan meningkat, secara tidak langsung tujuan dari pemasaran telah tercapai.

Menurut Hasan (2013), perilaku konsumen adalah studi proses yang terlibat ketika individu atau kelompok memilih, membeli, menggunakan atau mengatur produk, jasa, idea, atau pengalaman untuk memuaskan kebutuhan dan keinginan konsumen.

Perilaku konsumen merupakan dinamika interaksi antara pengaruh dan kesadaran, perilaku, dan lingkungan dimana manusia melakukan pertukaran aspek-aspek kehidupan, J.Paul Petter \& Jerry C Olson (2013). Berdasarkan pendapat yang dikemukakan oleh para ahli, maka perilaku konsumen dapat diartikan sebagai proses dan aktivitas ketika seseorang berhubungan dengan pencarian, pemilihan, pembelian, penggunaan, serta pengevaluasian produk demi memenuhi kebutuhan dan keinginan para konsumen.

\subsection{Keputusan Pembelian}

Menurut Kotler \& Amstrong (2014), keputusan pembelian merupakan bagian dari perilaku konsumen, perilaku konsumen yaitu studi tentang bagaimana individu, kelompok, dan organisasi memilih, membeli, menggunakan, dan bagaimana barang, jasa, ide atau pengalaman untuk memuaskan kebutuhan dan keinginan mereka. Menurut Buchari Alma (2013), keputusan pembelian adalah suatu keputusan konsumen yang dipengaruhi oleh ekonomi keuangan, teknologi, politik, budaya, produk, harga, lokasi, promosi, physical evidence, people dan proces. Keputusan pembelian tidak dapat dipisahkan dari sifat seorang konsumen, oleh karena itu konsumen cenderung memiliki kebiasaan yang berbeda-beda dalam hal melakukan suatu pembelian. diantara perilaku konsumen yang beragam termasuk juga dengan keputusan pembelian konsumen terhadap suatu produk. Menurut Kotler dan Keller (2016), Keputusan pembelian merupakan proses dimana konsumen melewati lima tahap, yaitu pengenalan masalah, pencarian informasi, evaluasi alternatif, keputusan pembelian, dan perilaku pasca pembelian.

Berdasarkan uraian yang dikemukakan oleh para ahli, pemahaman penulis tentang keputusan pembelian adalah cara seorang konsumen dalam mencari, dan membeli suatu produk dimana mereka akan memutuskan untuk membeli produk mana yang akan dibeli dari berbagai macam pilihan produk. artinya Sebelum memutuskan untuk melakukan suatu pembelian, konsumen terlebih dahulu akan mencari, menimbang, dan membandingkan produk satu dengan produk yang lainnya.

\section{METODOLOGI PENELITIAN}

\subsection{Jenis Penelitian}

Pada Penelitian ini menggunakan metode deskriptif dengan pendekatan kualitatif. Penelitian kualitatif adalah penelitian yang bermaksud untuk memahami fenomena tentang apa yang dialami oleh subjek penalitian misalnya perilaku, persepsi, motivasi, tindakan dan lainlain Sugiyono (2016). Dengan cara deskripsi dalam bentuk kata-kata dan bahasa, pada suatu 


\section{JURNAL EKONOMI DAN BISNIS VOL.2 NO.2 DESEMBER 2019}

http://jurnal.uts.ac.id

konteks khusus yang alamiah dengan memanfaatkan berbagai metode alamiah, Maka dalam penelitian ini penulis akan mendeskripsikan tentang perilaku konsumen dalam keputusan pembelian item pada game online PUBG mobile. Metode deskriptif yaitu penelitian yang diartikan sebagai cara ilmiah untuk mendapatkan data dengan kegunaan dan tujuan tertentu, Sugiyono (2016). Menurut Sujarweni (2015), deskriptif merupakan proses transformasi data penelitian dalam bentuk penyajian ringkasan sehingga mudah dipahami dan ditafsirkan.

\subsection{Objek dan Lokasi Penelitian}

Penelitian ini mengambil objek penelitian yaitu game online PUBG mobile, salah satu game online yang paling banyak diminati, jika dibandingkan dengan game online lainnya, selain itu game online PUBG mobile memiliki fenomena yang cukup menarik untuk diteliti. Lokasi penelitian yang berada dikota sumbawa pada kafe ruang temu.

\subsection{Data dan Sumber Data}

Data yang digunakan pada penelitian ini adalah adalah :

a. Data Primer

Menurut Rofland dalam Lexy J. Moleong (2012), sumber data utama dalam penelitian kualitatif ialah kata-kata dan tindakan. Data primer didapatkan secara langsung dari informan dengan melakukan wawancara dan observasi yang dilakukan dengan konsumen PUBG mobile yang telah melakukan pembelian item dalam game.

b. Data Sekunder
Data sekunder merupakan data yang di dapatkan melalui studi pustaka berupa jurnal, buku, dan sebagainya yang berhubungan dengan perilaku konsumen, keputusan pembelian dan game online PUBG mobile, kemudian studi pustaka tersebut diperoleh dari berbagai sumber. Dalam penelitian ini data sekunder digunakan oleh peneliti bertujuan untuk memperkuat dan melengkapi informasi yang diperoleh dari wawancara dan observasi.

\subsection{Analisis Data}

Menurut Sugiyono (2016) analisis data adalah proses mencari dan menyusun secara sistematis data yang diperoleh dari hasil wawancara, catatan lapangan, dan dokumentasi, dengan cara mengelompokan data ke dalam kategori, menyusun ke dalam pola, memilih mana yang penting dan mana yang akan dipelajari, dan membuat kesimpulan sehingga mudah dipahami. Dalam menganalisis data yang diperoleh dari penelitian dilapangan, peneliti menggunakan analisis model interaktif. Menurut Miles dan Huberman (1992) proses analisis model interaktif memiliki empat konponen yaitu, sebagai berikut :

a. Pengumpulan data

Dalam penelitian ini, pengumpulan data yang berwujud kata-kata dan bukan angka akan dikumpulkan melalui observasi, wawancara, dan intisari dokumen.

b. Reduksi data

Reduksi data dalam tahap ini sebagai proses pemilihan data dan informasi yang telah didapat dari penelitian di lapangan. pada tahap ini peneliti fokus pada penyederhanaan data 
yang diperoleh. Sehingga data yang diperoleh mampu diringkas dan peneliti dapat menemukan konsep-konsep serta pola-pola yang diinginkan sehingga bisa dijadikan dalam bentuk hasil akhir.

c. Penyajian data

Penyajian data merupakan suatu proses yang menyajikan data secara logis dan sistematis agar mudah untuk pemahaman apa yang terjadi. Oleh karena itu dibutuhkan penyajian yang jelas dan sistematis dalam penyelesain penelitian.

d. Kesimpulan

Melakukan penarikan kesimpulan dan verifikasi merupakan langkah terakhir yang di lakukan oleh penulis dalam penelitian ini. Kesimpulan dalam penelitian ini dapat menjawab dari rumusan masalah yang telah dirumuskan pada bab awal.

\section{KESIMPULAN DAN SARAN}

\subsection{Kesimpulan}

Penelitian ini bertujuan untuk menggambarkan perilaku konsumen PUBG mobile dalam melakukan keputusan pembelian item.

1. Faktor Usia memperngaruhi konsumen PUBG terhadap keputusan pembelian item pada game PUBG mobile, karena menurut para informan umur tiga puluhan yang dulu dan umur tiga puluhan yang sekarang itu berbeda, artinya umur tiga puluhan yang dulu belum mengenal game online dan smartphone bahkan sedikit pula yang mengenal internet, sedangkan umur tiga puluhan sekarang seakan-akan melekat dengan smartphone, internet bahkan game online, kemudahan dengan perkembangan teknologi saat ini yang mampu memudahkan pekerjaan seseorang salah satunya adalah memudahkan suatu pembelian secara online. Pada game online PUBG mobile juga menyediakan pembelian online yaitu item-item yang tersedia dalam game, hal tersebut tidak menutup kemungkinan bagi penikmat game PUBG mobile untuk melakukan suatu pembelian dalam game. ternyata dilihat dari segi faktor usia umur tiga puluhan kebawah cendrung hanya memainkan game PUBG saja dan jarang untuk melakukan pembelian item, sedangkan umur tiga puluh tahunan keatas lebih cendrung membeli item-item PUBG mobile dan waktu yang digunakan untuk bermain PUBG mobile tidak sebanyak waktu yang digunakan oleh unur tiga puluh tahun kebawah.

2. Faktor pekerjaan dan keadaan ekonomi berpengaruh terhadap keputusan pembelian item pada game online PUBG mobile, menurut para informan pekerjaan dan keadaan ekonomi dapat mempengaruhi seseorang untuk mau membeli atau tidak, karena pekerjaan dan keadaan ekonomi seseorang memiliki peran yang sangat penting terhadap keputusan pembeliannya.

3. Faktor gaya hidup berpengaruh terhadap keputusan pembelian item pada game online PUBG mobile, karena menurut para informan gaya hidup mereka seperti ini, suka bermain game online dan melakukan pembelian dalam game.

4. Faktor kepribadian dan konsep diri berpengaruh terhadap keputusan pebelian item pada game online PUBG mobile, menurut para informan kepribadian dan konsep diri terhadap kebiasaannya membeli barang yang tersedia dalam game, hal tersebut akan mempengaruhi 
pola pembelian item terhadap game-game

online yang mereka mainkan.

\subsection{Saran}

Berdasarkan hasil penelitian, pembahasan dan kesimpulan diatas, saran yang dapat diberikan adalah sebagai berikut.

1. Bagi konsumen PUBG mobile hendaknya mempertimbangkan terlebih dahulu sebelum melakukan pembelian pada game online PUBG mobile agar konsumen PUBG mobile tidak terlalu memenuhi kebutuhan yang tidak terlalu penting dalam kehidupan sehari-hari.

2. Bagi peneliti selanjutnya hendaknya menambahkan jumlah informan dan menggunakan lebih banyak teori perilaku konsumen yang telah dikemukakan oleh para ahli sehingga mampu mendapatkan hasil penelitian yang lebih efektif lagi.

\section{DAFTAR PUSTAKA}

Adam \& Rollings, 2007. Game online. Diakses maret 2017 dari http://www.designersnotebook.com.

Ali, Hasan. 2013. Marketing dan kasus-kasus pilihan. Yogyakarta. CAPS (Center for academic publishing service).

Alma, Buchari 2013. Manajemen Pemasaran dan Pemasaran jasa. Bandung: Alfabeta.

J. Paul Peter dan Jerry C Olson. 2013. Perilaku Konsumen dan Strategi Pemasaran. Jilid 1.

Khasan Umar. 2018. Analisi fakto-faktor yang mempengaruhi perilaku konsumen dalam pengambilan keputusan pembelian White Coffe. Cakrawala Jurnal. Vol.12, No.2 Desember 2018.

Kotler, Philip dan Amstrong, Gary. 2014. Prinsip pemasaran. Edisi 12, Jilid 1 Terjemahan Bob Sabran. Penerbit Erlangga, Jakarta.
Kotler, Philip dan Kevin Lane Keller. 2008. Manajemen Pemasaran, Jilid 1. Penerbit Erlangga, Jakarta.

Kotler, Phillip dan Kevin L. Keller. 2016. Marketing Manajemen. New Jersey: Pearson.

Moleong, Lexy J. 2012. Metodologi Penelitian Kualitatif. Bandung : PT Remaja Rosdakarya.

Mozza, benny. 2019. Bakar UC royale pass level 100 season 6 PUBG MOBILE INDONESIA. http://Youtube.com.

Putra Dwi Rizky, Widaningsih Sri. 2018. Analisis deskriptif faktor-faktor keputusan pembelian kartu simpati. E-Proceeding of Applied Science : Vol.4, No.1 Maret 2018.

Rakhma, Sakina. 2018. Berapa lama rata-rata orang indonesia menggunakan internet dalam sehari. https://kompas.com/2018/02/19.

Safar Ilham, Sari Kumala Novita. 2018. Keputusan pembelian konsumen jilbab pada mahasiswa kota makasar. Jurnal Seminar Pemasaran. Vol.5, No1 2018.

Selular.com. 2018. Pendapatan PUBG mobile catat rekor tertinggi. https://selular.id/2018/12/30.

Sugiyono. 2016. Metode penelitian pendidikan Pendekatan kuantitatif, Kualitatif, dan R\&B. Bandung: Alfabeta.

Sujarweni wiratna .v. 2015. Metodologi Penelitian Bisnis \& Ekonomi. Penerbit ,Pustaka Baru. Yogyakarta.

Sunyoto, Danang. 2014. Perilaku Konsumen dan Pemasaran. Jakarta: Caps

Wahyuni Sri, Amboningtyas Dheasey. 2015. Studi kulaitatif perilaku penggunaan jasa PPOB Korsis E-Payment. Jutnal Unpand.

Wikipedia. 2019. Battle royale game. https://en.m.wikipedia.org.

Yuliastuti, Desy. 2016. Manakah yang lebih banyak di dunia, smartphone android atau IOS. http://gadgetren.com/2016/11/11. 